\title{
Editorial: New Paradigms in Business: Engaging for Sustainability
}

\author{
Cathy Urquhart \& Olga Kuznetsova (Manchester Metropolitan University, UK)
}

At the time of writing this editorial, the UK was buffeted with strong winds and experienced the wettest winter since records began. These unusual weather patterns also occurred elsewhere in the winter of 2013 and 2014 in the Northern Hemisphere; for instance, unprecedented heavy snow in the US, and rare snow in the Middle East. Lord Stern, author of the influential Stern report (Stern 2006) on the economics of climate change, commented that events of this kind were clear indicators that the rate of climate change was greater than expected. 'Annual greenhouse gas emissions have increased steeply and some of the impacts, such as the decline of Arctic sea ice, have started to happen much more quickly' (Conal Urquhart writing in the Guardian, 13 February 2014).

There is a sense that the challenge of climate change is already upon us, and that all organisations, especially businesses, need to examine the ways they engage with sustainable transformations, and to do so with increasing urgency. Our special issue called for a focus on the firm level capacity to secure sustainable transformation as the societal level. Some researchers point to an obvious problem; in the conversation about sustainability in businesses, relatively little space is allocated to the implementation and the adequacy of adopted practices leading to sustainable outcomes (Robbins \& Page, 2012).

We are pleased to offer a range of papers in this special issue which discuss and showcase adopted sustainable practices, and explore possible future sustainable practices.

For businesses, the notion of sustainability of necessity means stepping out of narrow confines of what a business does, and thinking beyond economic considerations. Sustainable development encompasses three dimensions - economic, environment and social (OECD, 2005) and in our view these dimensions are not easily disentangled. At the same time, some would argue, these dimensions are not easily reconciled unless they are embedded into the core operations of organisations. It has been shown 
that sustainability agenda, in its widest sense, may only receive support from stakeholders if the issues it promotes are seen as relevant to organisations and people (Devinney, 2012). In our view, a new organisational mindset, consistent with the sustainability agenda and based on the concept of 'shared value' (Porter \& Kramer, 2011), requires a transition from self-awareness, social responsiveness and responsibility (when it might be sufficient to focus on minimising or avoiding harm to stakeholders and do the 'right' things) towards responsibility that implies 'doing the right things right' (Carroll, 1981; Carroll, 1999; Stiglitz, 2006; van Tulder, van Wijk \& Kolk, 2009; van Tulder \& van der Zwart, 2006).

The success of sustainability initiatives, however, stands or falls with organisations and stockholders who have adopted sustainability thinking. It has been suggested that sustainability thinking has the following features a) recognition of the widespread interdependence of species and ecosystems b) it always involves systems beyond the immediate focal organization c)understanding the presence of longer-term effects in addition to immediate short-term gains and d) multiple dimensions of performance beyond simple economic profits, e.g. social performance and cultural sustainability (Porter \& Derry, 2012). Sustainability thinking adds a new dimension to understanding success and value generation. For many years the Competing Values Framework (CVF), originally emerged from empirical research on the question of what makes organizations effective (Quinn \& Rohrbaugh, 1983), has been a leadership tool, a map, an organizing mechanism, a sense-making device in planning and explaining success. The application of a sustainability lens is rewriting the story of value creation. Of course, we would not claim that the adoption of sustainability into strategy and behavioural responses cancels the paradox that exists inherently in notions of effectiveness in organizations, as organizations pursue competing criteria simultaneously (Quinn, Faerman, Thompson, \& McGrath, 1996). Instead, it makes traditional prioritising of competing demands, defining organisational actions or even balancing them, insufficient and unsustainable. We would suggest that, in respect to sustainability, organisations have a rather limited choice: they cannot ignore it, as this option is not viable; their choice lies in choosing how to respond to the sustainability challenge in a number 
of ways. Robbins and Page (2012) effectively repackage the Competing Values Framework (CVF), into one that captures a wider range of business responses to sustainability claims. They suggest that organisations can choose to focus on either efficiency (e.g. energy consumption initiatives) or innovation (e.g. reconfiguring business processes) and also decide on whether to confine their responses to internal reforms or engage with the wider market (Figure 1). This model for actions shows, in fact, that as far as sustainability is concerned, the organisations do not have to prioritise; whatever they do, there a space for sustainability actions. The submissions in the special issue, in our view, provide convincing evidence on the feasibility and necessity of sustainability-driven approaches for all companies.

\section{Green Initiatives}

External (market)

\begin{tabular}{ll|l} 
& $\begin{array}{l}\text { Clean Brown } \\
\text { Products for remediation } \\
\text { Efficient versions of existing products } \\
\text { Sensors/thermostats/solar films } \\
\text { Pollution Mitigation } \\
\text { Waste Containment }\end{array}$ & $\begin{array}{l}\text { Grow Green } \\
\text { Novel ways to meet human needs: } \\
\text { System-changing innvation } \\
\text { Dematerialization (e.g. services vs. products) } \\
\text { Sustainable Technologies }\end{array}$ \\
Control/ & $\begin{array}{l}\text { Shrink Brown } \\
\text { Efficiency }\end{array}$ & $\begin{array}{l}\text { Live Green } \\
\text { System reconfigurations } \\
\text { "Tunneling through the cost barrier" }\end{array}$ \\
& $\begin{array}{l}\text { Governance Innovations } \\
\text { Reduce Consumption } \\
\text { Lean, Efficient Production }\end{array}$ & Eco-friendly Production
\end{tabular}

Internal

Figure 1. CVF with sustainability focus. Source: Robbins and Page (2012: 177)

Our special issue opens with an interview that Liz Walley, a senior lecturer in Management at MMU, has conducted with Sir Jonathon Porritt - founder director of Forum for the Future ${ }^{1}$ (see

1 Forum for the Future is described on its website as 'an independent non-profit working globally with business, government and other organisations to solve complex sustainability challenges' 
http://www.forumforthefuture.org/), environmentalist, author of the World We Made (Porritt 2013) and other books on the environment, and public figure of some note in the UK. This interview gives support to the proposition that self-interest drives sustainability at a company level, as illustrated by the discussion of how Marks \& Spencer that has conducted a very detailed analysis of how sustainability underpins the commercial priorities of the company, and how important it is for the company to own a sustainability agenda. The discussion between Liz and Jonathon on this gives us insights into understanding of what can be achieved in companies, and how to transfer 'responsibility' for sustainability to a company level and reconcile internal and external value orientation. One essential observation offered in the interview was that it would require a change of existing perceptions of leadership qualities: a modern leader should be imbued with a sustainability drive. Another important observation was that customers should also own sustainability agenda, and the relevant implementation tools.

Kokko, Lukkarinen and Mark-Herbert, continue the special issue with a masterly evaluation of public private partnerships (PPP) in the forestry sector in Scandinavia. In our view, their paper illustrates practices in the 'Grow Green' quadrant of Robbins and Page's (2012) framework, along the axes of external markets and innovation. Their paper, well grounded in the literature, gives a detailed picture of how three PPPs operate in the sector, and the varying motivations for such partnerships. Their paper shows that, when companies operate in a business closely scrutinised by both domestic and global stakeholders, decisionmaking becomes oriented towards the pursuit of the shared value creation. Such approaches, with a strong element of external orientation, allow an effective alignment of the social and private benefits for these business organisations.

By way of continuing the conversation on the customer's involvement in sustainability agenda, Langdown's commentary argues in favour of a slow fashion production-consumption model as a sustainable substitute, if not a formal alternative, to conventional modern fashion practices. Again, we would place this paper firmly in the 'Grow Green' quadrant of the Robbins and Page framework, because of 
the strong innovation strand and involvement of the customer in many of these slow fashion practices. This paper discusses a range of slow fashion practices, drawing on the ideas about sustainable fashion and steady state economics that could provide an antidote to fashion overload. Once again, in this article the suggestion is that sustainability is driven by novelty and innovation at the nexus that connects business with a customer.

The paper by Heyes invites us to consider the effects of sustainability demands for a conventional business - aviation - operating in an environment that is very sensitive to sustainability challenges. This paper examines the pressure on airport retail in a carbon-constrained world, and puts forwards a research agenda for transformative business models ensuring efficiency in this particular business environment. The paper suggests research issues located in the 'Live Green' and 'Grow Green' quadrants, with a special focus on finding new, and sustainable business models for airport retail.

Finally, an important aspect of sustainable organisational practices is the ability to manage those practices. Our final paper, by Silvius and Schipper, gives an analysis of how project management is responding to the sustainability challenge. Skilful management can deliver, we contend, on both innovation and efficiency, and as such, good project management can contribute to all four quadrants of the Robbins and Page framework. Silvius and Schipper reveal important gaps and deficiencies in the incorporation sustainability in current project management literature in their review of 164 articles, and identify areas of impact of sustainability concerns on traditional project management.

We hope that people find interest and inspiration in the special issue, and that the issue offers food for thought on how businesses can meaningfully engage with the sustainability challenge. One thread running through most of the pieces in this issue is that wider engagement with customers - and society in general - is a natural consequence of taking on the sustainability challenge. As Jonathon Porritt remarked in his visit to $\mathrm{MMU}$ on February $26^{\text {th }}$ of this year, there can be no sustainability without social justice. 
This special issue was coordinated by convenors of the Sustainable and Ethical Enterprise Group $(\mathrm{SEEG})^{2}$ at the Manchester Metropolitan University Business School. Our grateful thanks to the editorial assistants Anne Foy and Fiona Lees at Westburn, Michael Baker, Chief Editor of Social Business for accepting our proposal and supporting the special issue, our team of external reviewers, and last but not least, our two Associate Editors Patricia Rees and Chris Stone.

\section{References}

Carroll, A. (1981). Business and Society: Managing Corporate Social Performance. Boston: Little, Brown.

Carroll, A. (1999). Corporate social responsibility: Evolution of a definitional construct. Business \& Society, $38,268-295$.

Devinney, T. (2012). How to move sustainability up the list of individual concerns. Retrieved from http://www.modern-cynic.org/2012/07/12/how-to-move-sustainability-up-the-list-of-individual-concerns/.

OECD (2005). Measuring Sustainable Development. Statistics Brief, September No.10. Paris: OECD.

Porter, T., \& Derry, R. (2012). Sustainability and business in a complex world. Business and Society Review, 117(1): 33-53.

Porter, M. \& Kramer, M. (2011). Creating shared value. Harvard Business Review, 89, 62-77.

Robbins, GE and Page, M, Sustainability Initiatives: A Competing Values Framework, Competition Forum, ISSN 1545-2581, 01/2012, Volume 10, Issue 1, p. 176 -181

Quinn, R.E., Faerman, S.R., Thompson, M.P. \& McGrath, M.R. (1996). Becoming a Master Manager: A Competency Framework. New York: John Wiley.

\footnotetext{
${ }^{2}$ http://www.business.mmu.ac.uk/seeg/
} 
Quinn, R.E. \& Rohrbaugh, J. (1983). A spatial model of effectiveness criteria: Towards a competing values approach to organizational analysis. Management Science, 29(3): 363-377.

Urquhart C (2014) http://www.theguardian.com/environment/2014/feb/13/flooding-storms-uk-climatechange-lord-stern

Stiglitz, J. (2006). Making Globalization work. New York, NY: W.W. Norton \& Company.

Stern, N., (2006). The Economics of Climate Change: The Stern Review. Cambridge: Cambridge University Press.

Van Tulder, R., van Wijk, J. \& Kolk, A. (2009). A. From Chain Liability to Chain Responsibility. MNE Approaches to Implement Safety and Health Codes in International Supply Chains. Journal of Business Ethics, 85(Supplement 2): 399-412.

Van Tulder, R. \& van der Zwart, A. (2006). International Business-Society Management: Linking Corporate Responsibility and Globalization, Oxon: Routlegde. 